\title{
The Effect of The Political Environment and The Economic Environment on The Welfare of Community
}

\author{
Agus Tripriyono \\ Universitas Sumatera Utara \\ Medan, Indonesia \\ agustripriyono@usu.ac.id \\ Iskandar Muda \\ Universitas Sumatera Utara \\ Medan, Indonesia \\ iskandar1@usu.ac.id
}

\author{
Erlina \\ Universitas Sumatera Utara \\ Medan, Indonesia \\ erlina@usu.ac.id
}

\begin{abstract}
This study aims to examine the influence of the political environment and the economic environment on the welfare of society. The independent variable of this research is the political environment and the economic environment and its dependent variable is the welfare of society. This type of research is descriptive quantitative. The type of data used is the primary data using ordinal scale. The population is 295 respondents with selected sample type with Purposive Sampling as many as $\mathbf{2 0 5}$ respondents spread in North Sumatera Province. Analyzer used with Structural Equation Modeling approach with SMART-PLS software. The results show that the variables of the political environment and the economic environment affect the welfare of the people.
\end{abstract}

Keywords-political environment; economic environment; community welfare

\section{INTRODUCTION}

In developing countries, the political environment has a real effect on the success and failure of the company through the opportunities and business threats it generates. No less important than the economic environment, because often the market mechanisms in developing countries have not been fully and transparently working. The government has many reasons for nationalism, development acceleration, development equity, correction of market failure mechanisms to intervene. The government emerged as a mega and metaphor. There are still many investment decisions, allocation of funds, selection of partners is made more based on political considerations[1]. Therefore, executives in developing countries are required to have an understanding beyond simply understanding the ongoing political trends. They are always asked to be able to identify the real political actors who are the center of power by continuously updating the existing political map. Sustainable Development affirms the balance of the three pillars of social, economic, and environmental aspects [26]. Regional development strategy oriented to the fulfillment of the needs of a region to improve its function and role in organizing social life, economy, culture, education and community welfare. Community welfare is an important part of the development of a region, especially in rural areas that are very vulnerable and hard to face changes that are global scale [25]. The change should consider the aspects of sustainable development. One of those aspects is wise consideration in the utilization of the potential of natural resources to accelerate the welfare of the community.

Community welfare is a condition that shows community life that can be seen from the standard of community life. The income per capita level does not fully reflect the level of welfare because of the weakness that comes from imperfections in the calculation of national income and income per capita and the weakness that stems from the fact that the level of community welfare is not only determined by income levels but also other factors. [27]

Public welfare which is one indicator of the economic growth of a region is strongly influenced by the financial decisions made by the Regional Government [2]. According to the International City/County Management Association (ICMA), there are several factors that influence the local government's financial decisions. They are: (1) Political Environment, (2) economic environment, (3) Social environment, and (4) Legal environment [3]. Economic 
growth of North Sumatra Province have a positive growth in every single year. There was a significant increasing every year. Achieving the results of development is felt by the community was a development aggregate of 33 districts/cities in North Sumatra Province which. Those were the joint efforts between the government and the community. The economy of North Sumatra, measured by the increase of Gross Regional Domestic Product (GRDP) at constant price from 2010 to 2016 was 5.02 percent. Compared to 2015 there was acceleration 4.84 percent.

Based on the production approach, the highest growth was achieved by Health Service and social activities of 7.92 percent. The structure of the North Sumatra economy in the first quarter of 2016 was still dominated by three main business fields: agriculture, forestry, and fisheries by 22.89 percent; the processing industry by 19.28 percent; as well as large-retail trade and auto-motorcycle repairs by 17.71 percent. Based on the opinion of some experts under normal circumstances, increasing GDP is causing greater government revenue, but government spending is getting bigger. For local governments tax revenue is one of the most significant income posts. According to Peacok and Wiseman [4], that society has a level of tax tolerance, a level which people can understand the amount of taxes required by the government to finance government spending. Political conflicts can be nonpermanent, revolutionary, and/or disjointed; and basically can be categorized as riots, domestic war, and conspiracy. The riot (turmoil) is an instantaneous upheaval on a very large scale against the regime in power. The internal war means largescale organized violence against the government. Conspiracy is a planned and instantaneous action in the form of violence against the ruling party.

Political conflicts can affect business either directly or indirectly. Direct effects are forms of violence against corporations such as executive kidnappings, destruction of company property, labor strikes, and so on. The immediate effect is temporary and will not incur huge losses. Indirect effects occur because of policy changes within the government. In other words, political conflict causes some changes in the economic perspective of government. The change may come from the attitude of the ruling or new government. The change may be encouraged by good faith to fix things or to divert general attention from an internal problem.

Local governments should be able to operate their activities independently. Local government is required to improve its public services. Therefore, the local government expenditure focus in economic expenditure, social expenditure and infrastructure expenditure (also called by development expenditure) than indirect expenditure [12], [13], [14], [15]. Development expenditures were a logical effort undertaken by local governments to increase public confidence in order to improve the welfare of the community.
This research explores the perspective of local governments on the citizen survey, neighborhood forum, and town hall meeting-based governance entities being developed by these initiatives. It asks to what extent local government sees such efforts as appropriate responses to community needs, interests, and circumstances, or to what extent they might be seen as intruding into the representative and provisionary functions of local government [16]. Economic growth and unemployment have a close relationship due working people contribute to producing goods and services whereas unemployment does not contribute.

The welfare of the community in an area is affected by the financial decisions made by the local government concerned. As described early, local and central government financial decisions are strongly influenced by (1) the Political Environment, (2) the economic environment, (3) the Social environment, and (4) the legal environment [17] \& [18].Based on the previous explanation, the authors see the importance of doing research and analysis deeper to find a formula of financial decisions that will improve the welfare of the community In North Sumatra Province.

The model developed from the theories was :

Figure 1. Research Model

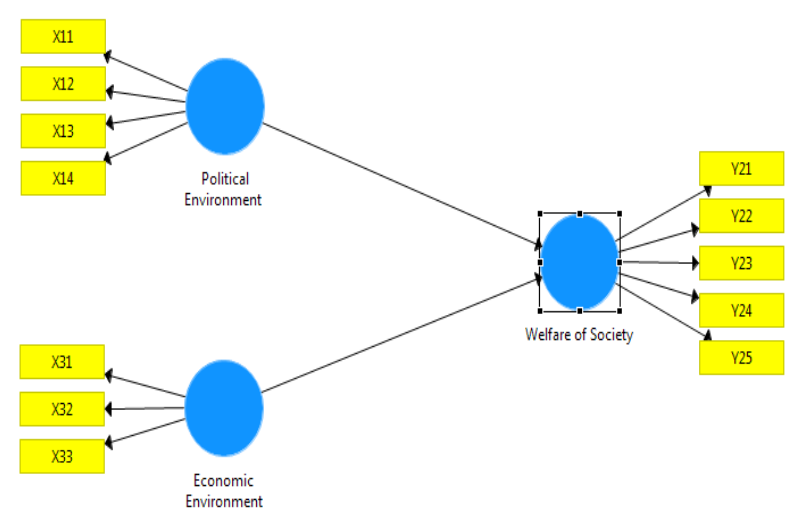

\section{METHOD}

This study uses primary data. The hypothesis was tested by using Structural Equation Modeling (SEM) with the aid of SMART PLS software. The data analysis technique in this research employed Structural Equation Modeling (SEM). SEM is a set of statistical techniques allowing testing of a series of relationships simultaneously. Furthermore, in the data processing, the writer used the aid from software SMART-PLS Structural Equation Modeling, which was one of the multivariate analyses capable of analyzing the variable relationships in complex manner [15], [16] \& [17]. The definition fo research variable is as the following: 
TABLE 1. Variable Measurement

\begin{tabular}{|c|c|c|c|c|}
\hline No. & Variable & Definition & Indicator & Scale \\
\hline 1. & $\begin{array}{l}\text { Political } \\
\text { Environment }\end{array}$ & $\begin{array}{l}\text { Community } \\
\text { involvement in } \\
\text { the process of } \\
\text { budgeting }\end{array}$ & $\begin{array}{ll}\text { 1. } & \text { Citizen surveys } \\
\text { 2. } & \begin{array}{l}\text { Neighborhood } \\
\text { forums }\end{array} \\
\text { 3. } & \begin{array}{l}\text { Town hall } \\
\text { meetings }\end{array} \\
\text { 4. } & \begin{array}{l}\text { Interactive } \\
\text { websites }\end{array}\end{array}$ & Likert \\
\hline 2. & $\begin{array}{l}\text { Economic } \\
\text { Environment }\end{array}$ & $\begin{array}{l}\text { Economic } \\
\text { condition } \\
\text { affecting the } \\
\text { budgeting } \\
\text { process }\end{array}$ & $\begin{array}{ll}\text { 1. } & \text { Economic cycle } \\
\text { 2. } & \text { Inflation } \\
\text { 3. } & \text { Interest Rate } \\
\text { 4. } & \text { Competition } \\
\text { between local } \\
\text { government }\end{array}$ & likert \\
\hline 7 & $\begin{array}{l}\text { Community } \\
\text { Welfare }\end{array}$ & $\begin{array}{l}\text { Community } \\
\text { welfare is a } \\
\text { condition that } \\
\text { shows } \\
\text { community life } \\
\text { that can be seen } \\
\text { from the } \\
\text { standard of } \\
\text { community life }\end{array}$ & $\begin{array}{ll}\text { 1. } & \text { revenue } \\
\text { 2. } & \text { healthy } \\
\text { 3. } & \text { education }\end{array}$ & Likert \\
\hline
\end{tabular}

The hypotheses were tested using Structural Equation Modeling (SEM) with AMOS software tools. The equation is formed as follows:

$$
\mathbf{Y}=\boldsymbol{\alpha}+\mathbf{b}_{1} \mathbf{X}_{1}+\mathbf{b}_{2} \mathbf{X}_{2}+\mathbf{e}
$$

$$
\begin{array}{ll}
\mathrm{X}_{1} & =\text { Political environment } \\
\mathrm{X}_{2} & =\text { Economic environment } \\
\mathrm{Y} & =\text { Community Welfare } \\
\mathrm{b} 1, \mathrm{~b} 2, \mathrm{~b} 3 & =\text { Coefficient } \\
\alpha & =\text { Constant } \\
\mathrm{e} & =\text { Error }
\end{array}
$$

This phase is done to test the suitability of the model to evaluate the goodness-of-fit index. Analysis using SEM requires some suitability index to measure the correctness of data and models to be filed.

\section{RESULT}

The measurement model links between latent variables with manifest variables as follows:

Figure2. Standardization Coefficient

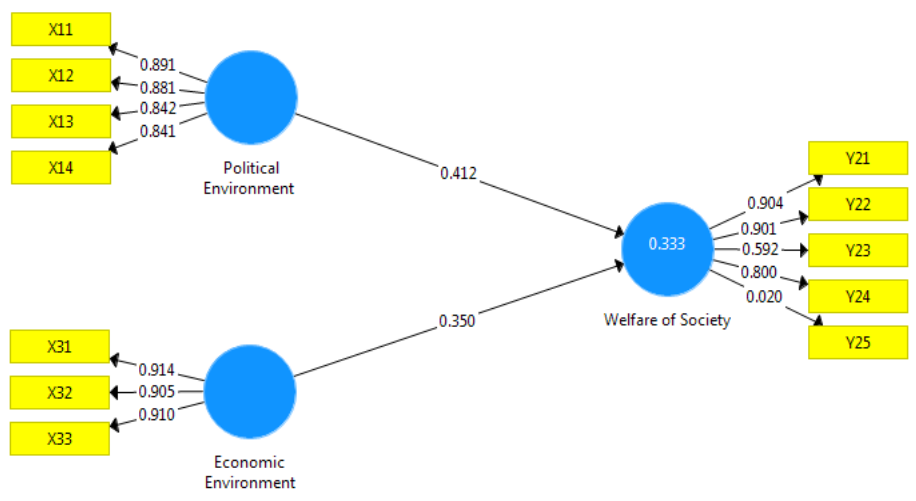

From the data processing the political environment and economic environment have a positive and significant effect on welfare of society. What appears to be occurring at the local level is that city and county managers and their legislative boards are increasingly using the budget to better understand how citizens, rather than internal participants, see government. The budget is the most important instrument in the economic policies of the Indonesian government and this represents a comprehensive statement of the State's priorities. As citizens, we also rely heavily on the state to provide crucial services and infrastructure. Public budget is a form of relationship between taxpayer citizens and apparatus. Such a transformation will have a major effect on budget allocations and the relative size of city and county agencies. Democracy in the last decade has also colored history in the political system in Indonesia. It is characterized by a person's freedom to express opinions through print and electronic media that are thought to be able to channel their ideas and voices. The development of the world of journalism which in the prereform era seems restrained by the Government also plays a role in guarding the transition of political system in Indonesia.

After the reform era, the once centralized governmental activities turned into decentralization in the form of broad, real and responsible autonomy. The authority of broad autonomy is the flexibility of the Region to administer the government which covers the authority of all areas of government, except for the authority in the field of foreign policy, defense, security, judiciary, monetary and fiscal, religious and other fields of authority to be stipulated by Government Regulation.

Public budget is no different from other budgets. That is how to make a choice between the possibilities of spending, balance and the process of deciding it. However, public 
budgets have a different kind, such as being open, involving different actors in their different purposes, using budget documents as a form of public accountability, and limitations to be considered. In fact, we should anticipate greater diversity among local governments in type and quality of services provided, particularly as communities develop reputations for having strengths in particular services. And given the powerful differences in service preferences that have been documented among age groups, we should also anticipate further segmentation of communities along generational lines. Types of citizen involvement to obtain citizen feedback:

- Citizen surveys

- Neighborhood forums

- Town hall meetings

- Interactive websites

The information obtained from public is very useful for the government. In fact, this community survey has not been implemented optimally. It is necessary to analyze how to form an effective survey so as to capture the aspirations of the community. Managers of private sector have learned how to getting closer to customers, understanding customer need and ensuring that their product and service meet customer need. Besides that private sector manager receive feedback continuously how well they are doing. A key to improving government performance, manager of public sector must get a better understanding of social needs. Public sector managers don't have mechanisms as gauge of their success. To minimize their feedback gap, some managers of government have used community needs assessment and other survey techniques like neighborhood forum to gauge the effectiveness of their operation, identify unmet public needs and improve public service.

Public participation is the process by which an organization consults with interested or affected individuals, organizations, and government entities before making a decision. Public participation is two-way communication and collaborative problem solving with the goal of achieving better and more acceptable decisions. Public participation in the process of implementation of financial management especially visible in the budgeting process [12], [13], [14] \& [15]. In the budgeting process, the local government has always held a Planning Meeting with public (in Indonesian is called Musrenbang)[2].

The research found that, in general, the citizen survey, neighborhood forum, and town hall meeting-based governance entities created by community-building initiatives are accepted by and acceptable to local governments. In fact, manager of local government sees a benefit in working with and through identifiable organizations and community leaders who can broker relationships and provide apparent legitimacy to government activities in the neighborhood. However, public officials did identify a number of limitations of such entities that they should inform but not make policy, that they cannot balance needs across constituencies citywide, that they lack accountability mechanisms, and that they cannot assume responsibilities that are assigned by statute to government. The result of this study support of [5]

Urban neighborhoods have been a recurring focus of social policy and organized social action in the United States at least since the Progressive Era [6] [7]. Efforts to organize social action at the neighborhood level to identify needs, deliver services, provide channels of communication to articulate grievances and express priorities, and engage in physical, commercial, and economic development have been fueled by actors in both the public and voluntary sectors.

In some cases, the relationship between the city and neighborhood-based governance structures has entailed a degree of devolution of authority over decision making (as with budget allocations for some infrastructure development projects) or management (as in coproduction arrangements for certain types of service delivery)[8], [9], \& [10]. These findings suggest that the notion of engaging citizen survey, town hall meeting and neighborhood forums level actors in aspects of governance and collective action beyond the formal political structures of local government and beyond the formal political process of voting continues to thrive in American cities. However, there is a lack of clarity (and, perhaps, agreement) about how best to structure relative roles, responsibilities, and appropriate forums for public debate and action. Further, community building initiatives are just one mechanism through which the functions of neighborhood based governance operate in any given local context [11], [12], [13], [19], [20]. To fully understand the potential (as well as the limitations) of the various approaches to neighborhood-based governance, we will have to focus on the relational aspects of their work, and on the components of successful negotiation between the entities, their constituencies, and the local government. More than a particular organizational structure or a formally acknowledged set of roles and relationships, the success of neighborhoodbased governance mechanisms seems dependent on the structuring of relationships and the ongoing negotiation of connections, responsibilities, expectations, and lines of accountability. Economic growth is a common indicator used to see the success of development. Economic growth is very important and needed, because without economic growth will not increase welfare, employment, productivity, and income distribution. Growth the economy is also important to prepare the economy to go through the stages of progress.

This research found that economic environment has a significant effect to community welfare, if there are a lower interest rate and the lower inflation will increase community welfare. And on the other hand, if 
there are high economic cycle and competition between local governmentwill be increased community welfare.

\section{CONCLUSIONS}

The result of this study found that political environment and economic environment have a significant effect on community welfare.

\section{References}

[1] Badaruddin. Utilization of Capital in Efforts toIncrease Family Welfare and Communities (Study on Rubber Farmers Community in Rao Subdistrict, Pasaman District, West Sumatera). Wahana Journal. Vol. 12 Issue. 2. (2006).pp.76-89.

[2] Erlina. ConflictofInterestImpact: FactorsAnalysisAffectingtheBudgetQualityinMedanCity. International Journal of Economic Research. Vol.14 Issue 12. (2017). pp.135-145.

[3] Peacock, Alan T., and Jack Wiseman. Peacock and Wiseman on Growth of Public Expenditure, Public Choice, Vol.78 Issue 2.(1994). pp.34-56.

[4] Chaskin, J. Robert \& Ali Abudimah, A View From The City: Local Government Perspectives On Neighborhood-Based Governance In Community-Building Initiatives. (2012).

[5] Halpern, Robert, Rebuilding the InnerCity: A History of Neighborhood Initiatives to Address Poverty in the United States. New York: Columbia University Press. 1995.

[6] Miller, Z. L. The role and concept of neighborhood in American cities. inCommunity organization for urban socialchange: A historical perspective, edited byR. Fisher and P. Romanofsky. Westport, Connecticut: Greenwood Press. pp. 3-32. 1981.

[7] Berry, Jeffrey M., Kent E. Portney and Ken Thompson. The rebirth of urbandemocracy. Washington, D.C.: The Brookings Institution. 1993.

[8] Sharp, Elaine B. Urban politics andadministration: From service delivery to economic development. White Plains, NY:Longman. 1990.

[9] Yates, Douglas. Neighborhood democracy:The politics and impacts of decentralization. Lexington, MA: Lexington Books. 1973.

[10] Muda, I., Rafiki, A., \& Harahap, M. R. Factors Influencing Employees' Performance: A Study on the Islamic Banks in Indonesia. International Journal of Business and Social Science, Vol.5Issue 2. (2014). pp. 7380.

[11] Dalimunthe, D.M.J.,Fadli, and Muda, I. The application of performance measurement system model using Malcolm Baldrige Model (MBM) to support Civil State Apparatus Law (ASN) number 5 of 2014 in Indonesia. International Journal of Applied Business and Economic Research. Vol.14 Issue 11. (2016). pp.7397-7407.

[12] Gusnardi, Riadi, R.M., and Muda, I. Competency mapping and analysis of students competency based on economics subject national examination and its alternative solutions in state high schools at Pekanbaru. International Journal of Economic Research. Vol.3 Issue 5. (2016). pp.2133-2148.

[13] Lubis, A.,Torong, Z.B., and Muda, I. The urgency of implementing balanced scorecard system on local government in North Sumatra Indonesia. International Journal of Applied Business and Economic Research. Vol.14 Issue 11. (2016). pp.7575-7590.
[14] Lubis, A.F., Lubis, T.A., and Muda, I. The role of Enterprise Resource Plan (ERP) configuration to the timeliness of the financial statement presentation. International Journal of Applied Business and Economic Research. Vol.14 Issue 11. (2016). pp.7591-7608.

[15] Lutfi, M.,Nazwar, C., and Muda, I Effects of investment opportunity set, company size and real activity manipulation of issuers in Indonesia Stock Exchange on stock price in Indonesia. International Journal of Economic Research. Vol.13 Issue 5. (2016). pp.2149-2161.

[16] Muda, I and Abykusno Dharsuky. Impact Of Region Financial Information System (SIKD) Quality, Role Ambiguity And Training on Precision of Financial Statement of Local Government Presentation In North Sumatra. International Journal of Applied Business and Economic Research, Vol.13 Issue 6. (2015). pp.4283-4304.

[17] Muda, I, DeniYuwilia Wardani, Erlina, Azhar Maksum, Ade Fatma Lubis and Rina Bukit. The Influence of Human Resources Competency and The Use of Information Technology on The Quality of Local Government Financial Report with Regional Accounting System as an Intervening. Journal of Theoretical and Applied Information Technology. Vol.95 Issue 17. (2017). pp.1432-1451.

[18] Muda, I, Dharsuky. A., Siregar, H.S., and Sadalia, I. combined loading and Cross-dimensional loadings timeliness of presentation of financial statements of local government. IOP Conference Series: Materials Science and Engineering. Bandung, (2017). 180. doi: 10.1088/1757899X/180/1/012099.

[19] Muda, I, Marlon Sihombing, Erni Jumilawati and Abikusno Dharsuky. Critical Success Factors Downstream Palm Oil Based Small And Medium Enterprises (SME) In Indonesia. International Journal of Economic Research. Vol.13 Issue 8. (2016). pp. 3531-3538.

[20] Muda, I, Mutia Ismail and Marhayanie. Impact Allocation Capital Expenditure on The Improvement of the Local Government Assets in North Sumatra and Effect on Local Revenue Sustainability. International Journal of Economic Perspectives. Vol.11 Issue 2. (2017). pp.151-164.

[21] Muda, I.,Dharsuky, A.,Sadalia, I., and Siregar, H.S. Impact of capital investments and cash dividend policy on Regional Development Bank (BPD) PT. Bank Sumut to the district own source revenue and economic growth. International Journal of Applied Business and Economic Research. Vol.14 Issue 11. (2016). pp.7863-7880.

[22] Muda, Iskandar. The Effect of Supervisory Board Cross-Membership and Supervisory Board Members' Expertise to The Disclosure of Supervisory Board's Report: Empirical Evidence From Indonesia. European Research Studies Journal. Vol.XX Issue 3A. (2017). pp.702716.

[23] Yahya, Idhar., Torong, Z.B., and Muda, I.. Influence Behavior in Legislature Budget Development of Regions in the Province of Aceh and North Sumatra". International Journal of Economic Research, Vol.14 Issue 8. (2017). pp. 147-159.

[24] Jain, C. Subhash. International Marketing Management. Salemba Empat Publishers. Jakarta. (2001).

[25] Karlsson, C., \& Stough, R. (Eds.). The Regional Economics of Knowledge and Talent: Local Advantage in a Global Context. Edward Elgar Publishing. (2012)

[26] Tavassoli, S., \& Karlsson, C. The role of regional context on innovation persistency of firms. Papers in Regional Science. (2017).

[27] Sihombing, Marlon; Muda, I, ErniJumilawati and AbikusnoDharsuky. "Factors Affecting The Success of Local Innovation Systems With Government Programs As Moderators". International Journal of Economic Research. Vol.14 No.16(2017)..pp.272-289. 